\title{
Cytotoxic Activity of Stem Bark Extracts from Canarium odontophyllum Miq (Dabai) against Human Colorectal Carcinoma HCT 116 Cell Line
}

\author{
Dayang Fredalina Basri1, Muhammad Arifuddin Al Rasyid Mohd1, Chan Kok Meng1, \\ Elda Surhaida Latif', Fahrul Zaman Huyop ${ }^{2}$ \\ ${ }^{1}$ School of Diagnostic \& Applied Health Sciences, Faculty of Health Sciences, Universiti Kebangsaan Malaysia, \\ Kuala Lumpur, Malaysia \\ ${ }^{2}$ Faculty of Biosciences and Medical Engineering, Universiti Teknologi Malaysia, Johor, Malaysia \\ Email: dayang@ukm.edu.my
}

Received 10 November 2014; revised 9 December 2014; accepted 15 December 2014

Copyright (C) 2014 by authors and Scientific Research Publishing Inc.

This work is licensed under the Creative Commons Attribution International License (CC BY). http://creativecommons.org/licenses/by/4.0/

(c) (i) Open Access

\begin{abstract}
The preliminary study is aimed at evaluating the cytotoxic activity of crude extracts from the stem bark of Canarium odontophyllum against colorectal carcinoma cell HCT 116. Result of the extraction yield showed that distilled water produced the highest yield $(10.58 \%)$ followed by methanol $(6.55 \%)$ whereas acetone extracted the lowest yield $(4.58 \%)$ from $C$. odontophyllum stem bark. Phytochemical screening test revealed the presence of terpenoid, flavonoid, tannin, saponin and phenolic compound in all the stem bark extracts of $C$. odontophyllum. Acetone extract of $C$. odontophyllum stem bark showed significantly higher $(\mathrm{p}<0.05)$ cytotoxic effect with $\mathrm{IC}_{50}$ of $0.062 \pm$ $1.04 \mathrm{mg} / \mathrm{ml}$ compared to methanol extract with $\mathrm{IC}_{50} 0.122 \pm 4.92 \mathrm{mg} / \mathrm{ml}$. No cytotoxic effect was observed by the aqueous extract despite its high extraction yield. In conclusion, acetone and methanol extracts from $C$. odontophyllum stem bark exhibited promising cytotoxic activity against human colorectal cancer cell line HCT 116 and paves way for further investigation in view of its mode of cancer cell death.
\end{abstract}

\section{Keywords}

Canarium odontophyllum, Stem Bark, Burseraceae, HCT 116, Cytotoxic Activity, Colorectal Carcinoma 


\section{Introduction}

Colorectal cancer (CRC) is the third most common malignant neoplasm in the world after breast and lung cancer, but it is more prevalent in developed countries [1]. In Malaysia, a high proportion of metabolic diseases such as hypertension and diabetes type 2 are linked with colorectal carcinomas [2]. In fact, the most common cancer among Malaysian men during the period of 2007 until 2011 was colorectal, followed by lung cancer whereas colorectal cancer came in second after breast cancer in women [3]. Colorectal cancer is the second most common cause of death with 3500 cases per year and has become a major public problem [4].

Globally, $80 \%$ of the population depends on traditional medicine for primary health care and an estimated 25\% of the drug or drugs used in the pharmaceutical industry are derived from natural plant [5]. It has recently been reported that "the use of natural products has become the single most successful strategy in the discovery of novel drugs" [6]. Historically since the 1950s, modern medicine began more systematically to examine the natural organisms as a source of useful anti-cancer specifically from plant, which has proven that its derivatives can be used for treatment or prevention of cancer in human [7]. According to Pezzuto [8], plant extracts have potential for use as a cancer chemotherapeutic agent as it can inhibit the process of carcinogenesis [9].

Canarium odontophyllum Miq. belongs to the Burseraceae family which can be found in the tropical rainforest of Sarawak, Malaysia particularly in the rural towns of Sarikei, Sibu and Kapit. The fruit or locally known as "dabai" among the Malaysian has an oblong-shaped with average length of $3-4 \mathrm{~cm}$, weighing $10-13 \mathrm{~g}$ and is usually consumed as a side meal [10]. The fruit is seasonal being only available during the period from October to December and along with its lack of promotion therefore, the economic potential of the fruit has not been fully explored and utilized [11]. Most of the previous literature reported pharmacological activity on the fruit of $C$. odontophyllum and until now, there is no past research conducted on the stem bark from C. odontophyllum. However, tannin extracted from the stem bark from Canarium album showed a very good DPPH radical scavenging activity and ferric reducing power [12] and the ethanol extract from the barks of Canarium patentinervium Miq. showed significant antimicrobial and radical scavenging activities which were attributed to the presence of tannin and flavonoids [13]. The present study was therefore, initiated from the success story of taxol from the bark of the Pacific yew tree, Taxus brevifolia, which was shown to kill ovarian cancer cells by promoting microtubule polymerization [14] and the willow bark extract which suppressed the growth and induced apoptosis in human colon cancer cells [15]. Bearing in mind of the anti-tumor property of constituents isolated from the bark of willow tree and Pacific yew tree, we therefore aimed to investigate the cytotoxic effect of bark extract from Canarium odontophyllum against human colorectal cancer cells HCT 116 and this is the first preliminary study which employed the stem bark from this underutilized plant as potential source of cytotoxic agent against colon cancer cell lines HCT 116.

\section{Materials and Methods}

\subsection{Plant Material}

Fresh stem bark of C. odontophyllum was flown in from Sarawak, Malaysia to the Herbarium Universiti Kebangsaan Malaysia in Bangi, Malaysia where it was authenticated and deposited in with voucher specimen No. UKMB40052. Prior to analysis, the fresh stem bark was washed thoroughly with clean wet cloth and was then spread on the tray to dry in the oven at $45^{\circ} \mathrm{C}$ for several days. The dried stem bark was ground into powder using an electrical blender.

\subsection{Preparation of Extracts}

Solvents with different degree of polarity namely acetone, methanol and distilled water were used for extraction. One hundred gram of the powdered stem bark C. odontophyllum were soaked each in $500 \mathrm{ml}$ acetone in the ratio of 1:5. The mixture was subjected to agitation using electrical shaker for 24 hours at room temperature. The mixture was then filtered using the Whatman filter paper No. 1 to collect the filtrate obtained. The process was repeated using the remaining residue with $500 \mathrm{ml}$ acetone. Both filtrates were then mixed and concentrated under reduced pressure using a rotary evaporator. The extracts obtained were finally pounded to dryness under fume hood in order to produce a crude acetone extract. The same procedure was repeated in the preparation of methanol extract.

In the preparation of aqueous extract, the mixture of the powdered bark in distilled water was centrifuged at 
$3000 \mathrm{rpm}$ for $5 \mathrm{~min}$. The supernatant was then collected and the whole process was repeated using the remaining residue with $500 \mathrm{ml}$ distilled water. The supernatant was combined and freeze-dried at $-50^{\circ} \mathrm{C}$ under vacuum for 12 hours in order to produce a fine crystal-like crude aqueous extract. All the extracts were stored in air-tight jars at $4^{\circ} \mathrm{C}$ until further use.

The acetone and methanol extracts were dissolved with 100\% DMSO whereas the aqueous extract was dissolved in sterile distilled water to a final concentration of $0.0625 \mathrm{mg} / \mathrm{ml}, 0.125 \mathrm{mg} / \mathrm{ml}, 0.25 \mathrm{mg} / \mathrm{ml}, 0.5 \mathrm{mg} / \mathrm{ml}$ and $1 \mathrm{mg} / \mathrm{ml}$. All the extracts were sterilized by passing through a $0.22 \mu \mathrm{m}$ membrane filter.

\subsection{Phytochemical Screening}

Phytochemical screening assay used in this study was a modification of the previous literature [16]. Phytoconstituent tests were carried out for terpenoids, flavonoids, alkaloids, tannins, saponins and phenolic compounds. For terpenoid identification test, $2 \mathrm{mg}$ of each extract was dissolved in $2 \mathrm{~mL} \mathrm{CHCl}{ }_{3}$ followed by drops of $\mathrm{H}_{2} \mathrm{SO}_{4}$. Positive indication for the presence of terpenoid was determined by the formation of reddish brown. For flavonoid identification test, about $2 \mathrm{mg}$ of each extract was dissolved with $1 \mathrm{M} \mathrm{NaOH}$ followed by drops of $0.6 \mathrm{M}$ $\mathrm{HCl}$. The yellowish orange of $\mathrm{NaOH}$ that turns to colorless upon the addition of $\mathrm{HCl}$ confirmed that flavonoid was present. For alkaloid identification test, $5 \mathrm{mg}$ of each extract was dissolved in distilled water and was added with 3 drops of Wagner's reagent to form a blue-black precipitate reveal the positive test. For tannin identification test, $2 \mathrm{mg}$ of each extract in $5 \mathrm{~mL}$ of distilled water were mixed with a few drops of $15 \% \mathrm{FeCl}_{3}$. The formation of blue black precipitate and brownish green precipitate indicated the presence of hydrolysable tannin and condensed tannin, respectively. Saponin test was done by dissolving $5 \mathrm{mg}$ of each extract with $5 \mathrm{~mL}$ distilled water. The mixture was then heated and shaked and the resulting formation of froth indicated positive result. For phenolic compound identification test, about $2 \mathrm{mg}$ of each extract in $2 \mathrm{~mL}$ of distilled water followed by drops of $1 \% \mathrm{FeCl}_{3}$ to produce blue, black or green precipitate revealed the presence of phenolic compound.

\subsection{Preparation of Cell Culture}

HCT 116 cell line was obtained from American Type Culture Collection (ATCC) (Rockville, MD USA) (ATCC Number: CCL-247TM). The cell was cultured in McCoy 5A media (1×) (Sigma-Aldrich, USA). Culturing of the HCT 116 cell line was carried out in a sterile laminar flow chamber to avoid any contamination. Human colorectal cancer cells HCT 116 was cultured in McCoy 5A media and was completed with the addition of $10 \%$ calf serum. Cells in an incubator were at high humidity incubation environment of $5 \%$ carbon dioxide $\left(\mathrm{CO}_{2}\right)$ and at a temperature of $37^{\circ} \mathrm{C}$. The cultured cells were observed and checked daily by using inversion microscope to see the morphology and cell growth, while ensuring that no contamination occurs in a culture flask. The cells were sub-cultured up to $70 \%$ - 90\% collisions between the cells. Then phosphate buffer saline (PBS) was used to rinse the excess media. In addition, the solution of Trypsin-EDTA ( $0.25 \%$ Trypsin/EDTA $0.03 \%$ per annum) was also used to remove the cells from the surface of the tissue culture flask.

\subsection{Evaluation of Cytotoxic Activity}

MTT assay was performed based on a modification of a previous method [17]. A total of $200 \mu 1$ HCT 116 cells at a concentration of $5.0 \times 10^{4}$ cells $/ \mathrm{ml}$ were seeded into the wells of 96-microtiter plate. The cells were incubated for 24 hours to ensure their attachment to the surface of the wells. Then the cells were treated with each of the extracts at $1 \mathrm{mg} / \mathrm{ml}$ as well as menadione $(1 \mu \mathrm{M})$ as a positive control. A total of $20 \mu \mathrm{l}$ of MTT solution concentration at $5 \mathrm{mg} / \mathrm{ml}$ was added to each of the wells for 24 hours after treatment. The plates were incubated in an incubator at $37^{\circ} \mathrm{C}$ with $5 \% \mathrm{CO}_{2}$ for 4 hours. Consequently, $200 \mu \mathrm{DMSO}$ was added to each well to dissolve the formazan crystals at room temperature. The plates were then incubated in the incubator for 15 minutes. The plate was shaken on an automatic mixer for 5 minutes and the results were recorded using an ELISA plate reader at a wavelength of $570 \mathrm{~nm}$. The cytotoxic effect was measured and the addition of MTT was conducted in the dark room to avoid degradation of the active ingredient which was photosensitive. As for control, the blank compound was used in the absence of cell lines. The results were recorded as $\mathrm{IC}_{50}$ value which represented the concentration of the cytotoxic agent that inhibits the growth of cancer cells using the formula given below:

$$
\% \text { Cell viability }=\frac{\text { Absorbance of treated sample }(\text { mean })}{\text { Absorbance of control }(\text { mean })} \times 100 \%
$$


The percentage of cell viability against the concentration of test compounds was plotted. The half maximal inhibition concentration $\left(\mathrm{IC}_{50}\right)$ was calculated based on the equation in the plotted graph.

\subsection{Statistical Analysis}

Data were presented as mean \pm standard error mean (SEM). The results were analysed using Statistical Package for the Social Sciences (SPSS) version 16. Statistical significance was determined by student t-test and $\mathrm{p}$ value less than 0.05 was considered as significant.

\section{Results}

Table 1 showed the result of the percentage yield of extracts from the powdered bark of C. odontophyllum in acetone, methanol and distilled water as extraction solvents. Out of the three extracts, aqueous extract produced the highest yield of $10.58 \%$. Methanol extract was produced from $6.55 \%$ of dried powdered bark. The lowest yield was recorded by the acetone extract at $4.58 \%$. Distilled water was capable of producing the crude extract more than 2 times that of acetone as the extraction solvent. On the other hand, methanol was found to have the same extractive potential as acetone.

As shown in Table 2, the phytochemical screening result revealed that the three extracts contained all the phytoconstituents tested except alkaloid. Flavonoid, tannin, saponin, terpenoid and phenolic compounds were found to be present in the acetone, methanol and aqueous extracts from C. odontophyllum bark. However, the concentration of these phytoconstituents was not determined because the aim of the present study was to correlate the presence or absence of the phytochemicals responsible for the cytotoxic activity of the crude extracts from the stem bark of the plant.

From the preliminary result for cytotoxic screening of the stem bark extracts from C. odontophyllum, the HCT116 cell line was not inhibited by the aqueous extract at the range of concentration studied. From Figure 1, acetone extract displayed the strongest cytotoxic effect with $\mathrm{IC}_{50}$ value of $0.062 \pm 1.04 \mathrm{mg} / \mathrm{ml}$ whereas the methanol extract was shown to be moderately cytotoxic against HCT 116 cell with $\mathrm{IC}_{50}$ of $0.122 \pm 4.92 \mathrm{mg} / \mathrm{ml}$ (Figure 2). It was demonstrated that the cytotoxic effect of the acetone was significantly higher $(\mathrm{p}<0.05)$ than the methanol extract. However, since the $\mathrm{IC}_{50}$ value could not be obtained for aqueous extract therefore, it is assumed that the $\mathrm{IC}_{50}$ to be more than $1 \mathrm{mg} / \mathrm{ml}$ as shown in Figure 3. With respect to positive control, menadione was cytotoxic towards HCT116 cell at IC ${ }_{50}$ of $0.120 \mu \mathrm{M}$ (Figure 4).

Table 1. Percentage yield of various solvent extracts from Canarium odontophyllum.

\begin{tabular}{cccc}
\hline Solvents & Weight of powder sample (g) & Weight of sample extract (g) & Percentage of yield (\%) \\
\hline Acetone & 84.22 & 3.86 & 4.58 \\
Methanol & 83.79 & 5.49 & 6.55 \\
Aqueous & 100 & 10.58 & 10.58 \\
\hline
\end{tabular}

Table 2. The results of the phytochemical screening in acetone, methanol and aqueous extracts from C. odontophyllum stem bark.

\begin{tabular}{|c|c|c|c|}
\hline Phytochemical content & Acetone extract & Methanol extract & Aquoeus extract \\
\hline Flavonoid & + & + & + \\
\hline Tannin & + & + & + \\
\hline Saponin & + & + & + \\
\hline Alkaloid & - & - & - \\
\hline Terpenoid & + & + & + \\
\hline Phenolic compound & + & + & + \\
\hline
\end{tabular}

$(+)$ : Presence of constituent; (-): Absence of constituent. 


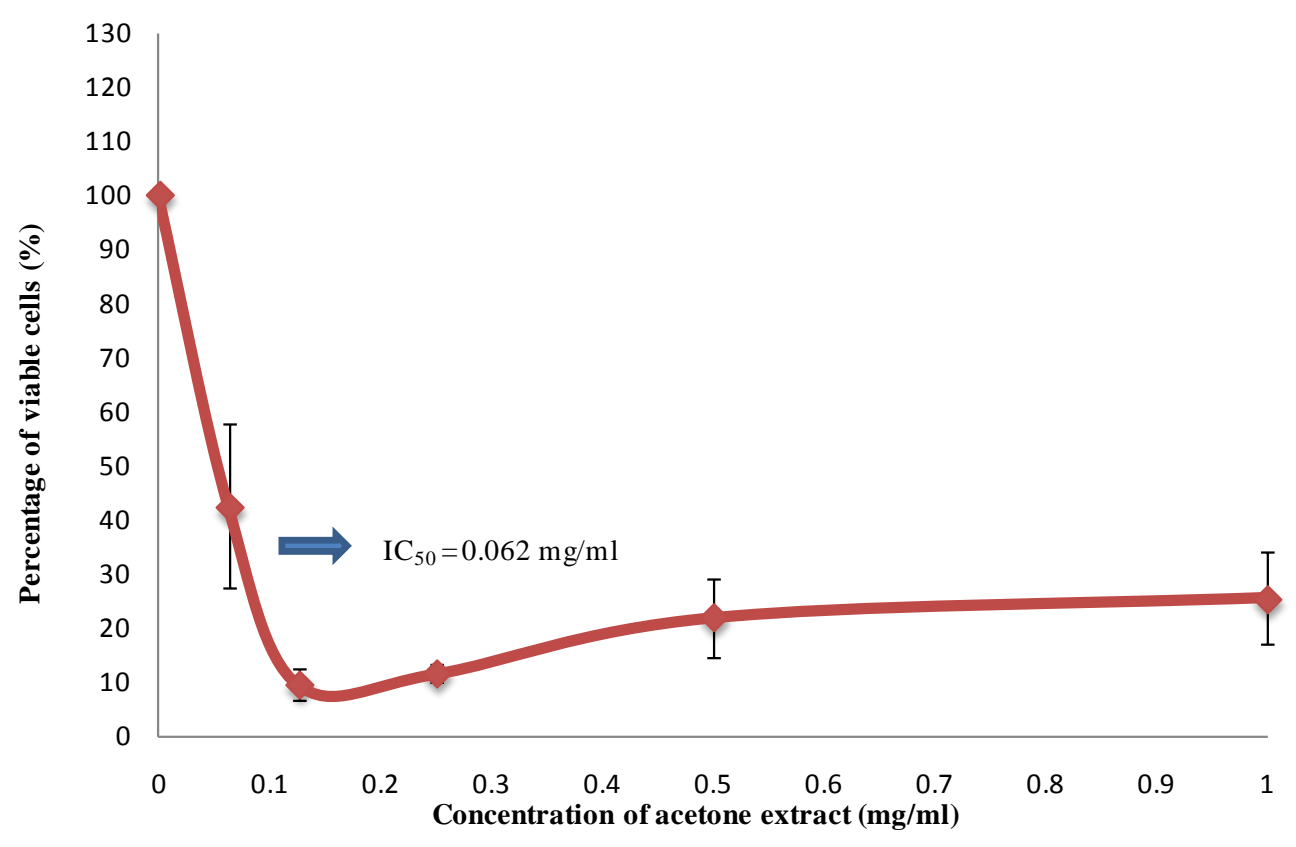

Figure 1. Cytotoxic effect of acetone extract from stem bark of $C$. odontophyllum on HCT116 cell viability at concentration range $0-1 \mathrm{mg} / \mathrm{ml}$ following 24 hours of treatment. Each point represents the mean of triplicates from 3 different experiments \pm SEM.

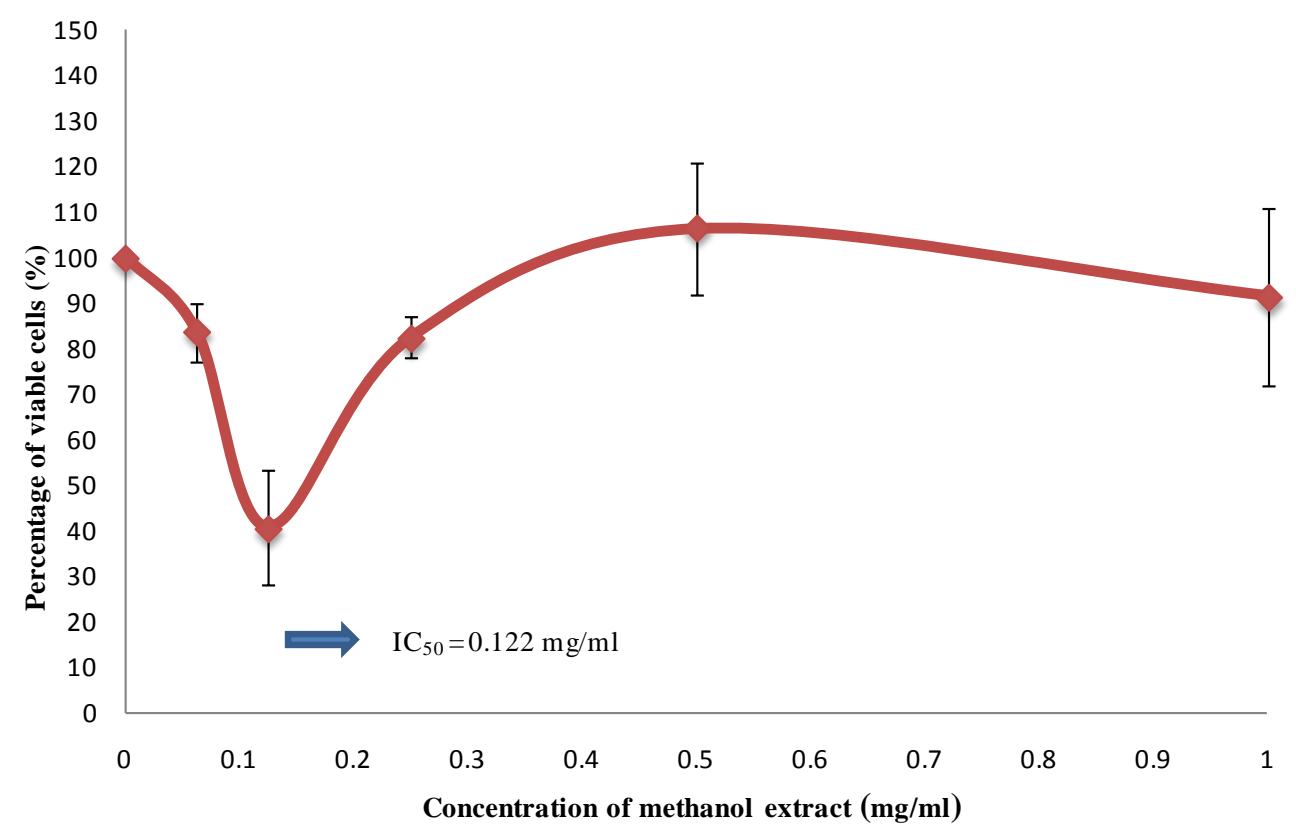

Figure 2. Cytotoxic effect of methanol extract from stem bark of C. odontophyllum on HCT116 cell viability at concentration range $0-1 \mathrm{mg} / \mathrm{ml}$ following 24 hours of treatment. Each point represents the mean of triplicates from 3 different experiments \pm SEM.

\section{Discussion}

Our findings demonstrated that water appeared to be the best solvent in the extraction of polar components from the stem bark of $C$. odontophyllum. This is in consistent with [18] that water extracted the highest yield of phenolic compounds from the seed of Agriophyllum pungens. In another study [19] which compared the extractive potential of water, acetone and ethanol from the bark of Pinus radiate, the largest yield was also obtained using 


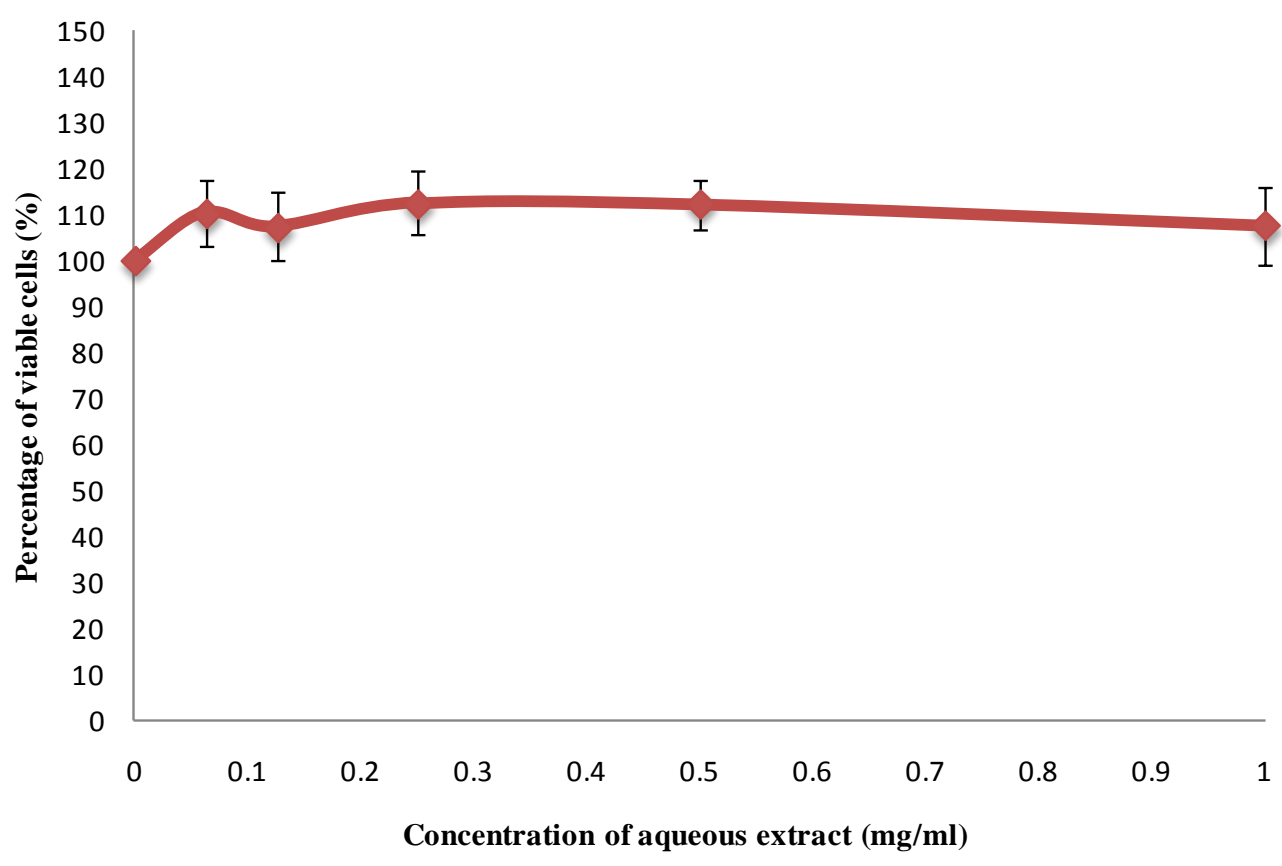

Figure 3. Cytotoxic effect of aqueous extract from stem bark of C. odontophyllum on HCT116 cell viability at concentration range $0-1 \mathrm{mg} / \mathrm{ml}$ following 24 hours of treatment. Each point represents the mean of triplicates from 3 different experiments \pm SEM.

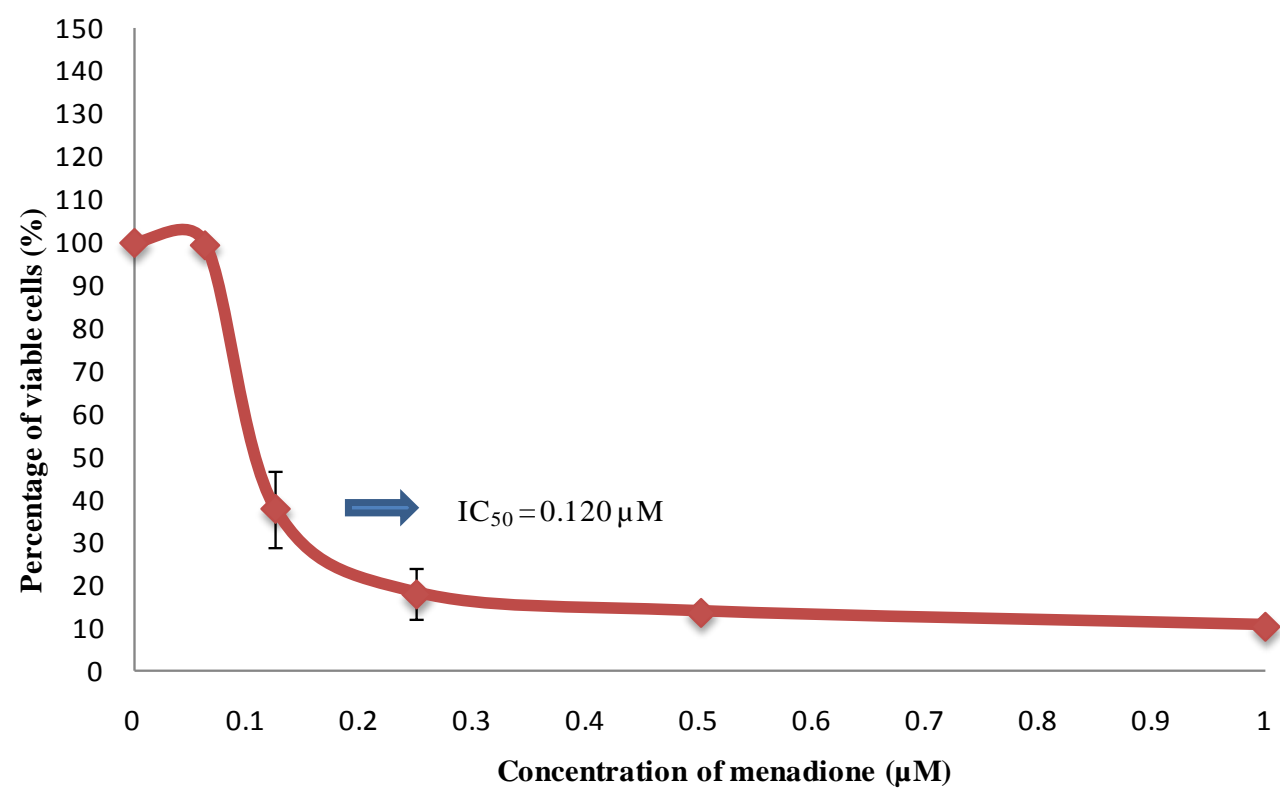

Figure 4. Cytotoxic effect of menadione on HCT116 cell viability at concentration range $0-1 \mu \mathrm{M}$ following 24 hours of treatment. Each point represents the mean of triplicates from 3 different experiments \pm SEM.

water as an extraction solvent. Hence, it can be postulated that the most polar solvent produced the highest yield from the bark extract of $C$. odontophyllum. On the other hand, acetone extract resulted in the lowest percentage yield of extract from C. odontophyllum bark which is supported by [20] that the extractive yield from the stem bark of Alstonia scholaris and stem of Tinospora cordifolia were lower in acetone compared to methanol as extraction solvent. This is probably because acetone is incapable of dissolving polar compounds from the bark of C. odontophyllum as in agreement with [21] that acetone is not a suitable solvent in extracting polar compounds 
like phenols due to its nonpolar entity.

The stem barks of $C$. odontophyllum extracted by acetone, methanol and distilled water indicated the presence of flavonoid, tannin, saponin, terpenoid and phenolic compounds. Phenolic compounds account for the protection against carcinogenesis, antioxidant and cytotoxic effects towards cancer cells. Among the phenols found in natural products, flavonoid contributes to the significant share of phenolic compounds [22]. It is postulated that phenolic compounds specifically flavonoid and tannin in the barks of $C$. odontophyllum might be responsible for the cytotoxic activity of acetone and methanol extracts against HCT 116 cell line in the present study. Previous study [23] reported that ethanol extracts from the stem barks of Canarium patentinervium Miq. accumulate substantial amounts of flavonoids and tannins which could be well correlated with the activities measured against HCT 116. The significantly higher cytotoxic activity demonstrated by the acetone extract from C. odontophyllum compared to its methanol extract against HCT 116 cells was in accordance with [24] that reported acetone extract from the stem bark of Cephalotaxus griffithii contained the highest amount of total phenolics and flavonoids and showed a more effective cytotoxicity than the methanol extract towards HeLa cells. However, the low extraction yield of acetone extract which indicated that less amount of polar components including phenolic compounds, flavonoid and tannnin were dissolved, the significantly stronger cytotoxic effect of acetone extract than methanol extract could possibly be attributed to the presence of terpenoid, which generally tend to be less polar. Terpenoid from the bark extracts of Cryptomeria japonica was shown to display cytotoxic effect against oral squamous cell carcinoma KB [25]. Therefore, the presence of terpenoid from the acetone extract of $C$. odontophyllum stem barks could possibly accounted for its anti-proliferation effect against HCT 116 colon cancer cell line. On the other hand, methanol as an extraction solvent is capable of dissolving various polar compounds as well as certain group of non-polar compounds which are fairly soluble in it [26] and as such, the lesser cytotoxic activity of methanol extract in comparison to the acetone extract may be due to these variety of phytoconstituents acting in antagonism to reduce the cytotoxic effect against HCT 116 cell line. This is in line with [27] that despite potentially valuable combination of phytochemicals in combating cancer drug resistance, the different phytochemicals can show opposing effects to produce antagonism.

The lower $\mathrm{IC}_{50}$ value indicates that the anti-cancer agent has stronger cytotoxic effect against the cell lines. Despite its highest extraction yield, aqueous extract produced $\mathrm{IC}_{50}$ value greater than $1 \mathrm{mg} / \mathrm{ml}$ in the MTT screening assay. The absence of cytotoxic activity by the aqueous extract against HCT 116 cells could be due to the using distilled water in the extraction of the phytocompounds from the stem bark of C. odontophyllum. Water as an extraction solvent, results in producing high content of impurities such as organic acids, sugars and soluble proteins along with polar compounds which could interfere with the identification and quantification of anti-proliferation components with cytotoxic potential [28].

\section{Conclusion}

In conclusion, the acetone extract of $C$. odontophyllum stem bark which showed absence of alkaloid content, displayed promising cytotoxic activity against human HCT116 colon cancer cell line. However, further work on the evaluation of cytotoxic effect of $C$. odontophyllum stem bark extracts is in progress in order to determine the mechanism of cancer cell death. In addition to this, assessment of its cytotoxic effect on the normal colon cancer cells is also ongoing to determine its safety profile prior to development as an anti-colon cancer agent.

\section{Acknowledgements}

The authors would like to thank Associate Professor Dr. Nor Fadilah Rajab from Universiti Kebangsaan Malaysia for her advice and consultation. This project is funded by the Government of Malaysia under the Ministry of Higher Learning (Fundamental Research Grant Scheme FRGS/1/2012/SG06/UKM/02/7).

\section{References}

[1] American Cancer Society (2014) Cancer Facts and Figures. Atlanta, 11-12.

[2] Othman, N.H. and Zin, A.A. (2008) Association of Colorectal Carcinoma with Metabolic Diseases; Experience with 138 Cases from Kelantan, Malaysia. Asian Pacific Journal of Cancer Prevention, 9, 747-751.

[3] Norwati, D., Harmy, M.Y., Mohd Noor, N. and Amry, A.R. (2014) Colorectal Cancer Screening Practices of Primary Care Providers: Results of a National Survey in Malaysia. Asian Pacific Journal of Cancer Prevention, 15, 2901-2904. 
[4] Center, M.M., Jemal, A., Smith, R.A. and Ward, E. (2009) Worldwide Variations in Colorectal Cancer. CA: A Cancer Journal for Clinicians, 59, 366-378. http://dx.doi.org/10.3322/caac.20038

[5] Payne, G.F., Bringi, V., Prince, C. and Shuler, M.L. (1992) Plant Cell and Tissue Culture in Liquid Systems. Hanser Publication, Munich, 1-10.

[6] Tulp, M. and Bohlin, L. (2002) Functional versus Chemical Diversity: Is Biodiversity Important for Drug Discovery? Trends in Pharmacological Sciences, 23, 225-231. http://dx.doi.org/10.1016/S0165-6147(02)02007-2

[7] Cragg, G.M. and Newman, D.J. (2005) Plants as a Source of Anti-Cancer Agents. Journal of Ethnopharmacology, 100, 72-79. http://dx.doi.org/10.1016/j.jep.2005.05.011

[8] Pezzuto, J.M. (1997) Plant-Derived Anticancer Agents. Biochemical Pharmacology, 53, 121-133. http://dx.doi.org/10.1016/S0006-2952(96)00654-5

[9] Chow, L.M.C., Chui, C.H., Tang, J.C.O.T, Teo, I.T.N., Lau, F.Y., Cheng, G.Y.M., Wong, R.S.M., Leung, T.W.T., Lai, K.B., Yau, M.Y.C., Gou, D. and Chan, A.S.C.C. (2003)Gleditsia sinensis Fruit Extract Is a Potential Chemotherapeutic Agent in Chronic and Acute Myelogenous Leukemia. Oncology Reports, 10, 1601-1607. http://dx.doi.org/10.3892/or.10.5.1601

[10] Chew, L.Y., Amin, I., Azrina, A. and Lau, C. (2012) Canarium odontophyllum Miq.: An Underutilized Fruit for Human Nutrition and Sustainable Diets. Sustainable Diets and Biodiversity, 5, 126-137.

[11] Basri, D.F., Fudholi, A. and Ruslan, M.H. (2012) Drying Characteristics of the Borneo Canarium odontophyllum (dabai) Fruit. American Journal of Agricultural and Biological Sciences, 7, 347-356. http://dx.doi.org/10.3844/ajabssp.2012.347.356

[12] Zhang, L.-l. and Lin, Y.-M. (2008) Tannins from Canarium album with Potent Antioxidant Activity. Journal of Zhejiang University Science B, 9, 407-415.

[13] Mogana, R., Khoo, T.J. and Wiart, C. (2011) In Vitro Antimicrobial, Antioxidant Activities and Phytochemical Analysis of Canariumpatentinervium Miq. from Malaysia. Biotechnology Research International, 2011, Article ID: 768673. http://dx.doi.org/10.4061/2011/768673

[14] Wani, M.C., Taylor, H.L., Wall, M.E., Coggon, P. and McPhail, A.T. (1971) Plant Antitumor Agents VI. The Isolation and Structure of Taxol, a Novel Antileukemic and Antitumor Agent from Taxus brevifolia. Journal of the American Chemical Society, 93, 2325-2327. http://dx.doi.org/10.1021/ja00738a045

[15] Hostanska, K., Jürgenliemk, G., Abel, G., Nahrstedt, A. and Saller, R. (2007) Willow Bark Extract (BNO1455) and Its Fractions Suppress Growth and Induce Apoptosis in Human Colon and Lung Cancer Cells. Cancer Detection and Prevention, 31, 129-139. http://dx.doi.org/10.1016/j.cdp.2007.03.001

[16] Anyasor, G.N., Ogunwenmo, K.O., Oyelana, O.A. and Akpofunure, B.E. (2010) Phytochemical Constituents and Antioxidant Activities of Aqueous and Methanol Stem Extract of Costus afer Ker Gawl. (Costaceae). African Journal of Biotechnology, 9, 4880-4884.

[17] Mosmann, T. (1983) Rapid Colorimetric Assay for Cellular Growth and Survival: Application to Proliferation and Cytotoxicity Assays. Journal of Immunological Methods, 65, 55-63. http://dx.doi.org/10.1016/0022-1759(83)90303-4

[18] Birasuren, B., Kim, N.Y., Jeon, H.L. and Kim, M.R. (2013) Evaluation of the Antioxidant Capacity and Phenolic Content of Agriophyllum pungens Seed Extracts from Mongolia. Preventive Nutrition and Food Science, 18, 188-195. http://dx.doi.org/10.3746/pnf.2013.18.3.188

[19] Ramos, V., Bocalandro, C., Riquelme, S., Sanhueza, V., Aspe, E., Roeckel, M. and Fernandez, K. (2013) Effect of the Bench Scale Extraction Conditions on Pinus radiata Bark Extract Yield, Antioxidant Properties and Composition. Maderas. Ciencia y Tecnologia, 15, 31-44. http://dx.doi.org/10.4067/S0718-221X2013005000003

[20] Bharat Gami, B. and Parabia, F. (2011) Screening of Methanol \& Acetone Extract for Antimicrobial Activity of Some Medicinal Plants Species of Indian Folklore. International Journal of Research in Pharmaceutical Science, 2, 69-75.

[21] Bandar, H., Hijazi, A., Rammal, H., Hachem, A., Saad, Z. and Badran, B. (2013) Techniques for the Extraction of Bioactive Compounds from Lebanese Urtica dioica. American Journal of Phytomedicine and Clinical Therapeutics, 6 , 507-513.

[22] Harborne, J. (1998) Phytochemical Methods: A Guide to Modern Techniques of Plant Analysis. Chapman and Hall, London.

[23] Mogana, R., Bradshaw, T.D., Jin, K.T. and Wiart, C. (2011) In Vitro Antitumor Potential of Canariumpatentinervium Miq. Academic Journal of Cancer Research, 4, 1-4.

[24] Moirangthem, D.S., Talukdar, N.C., Kasoju, N. and Bora, U. (2012) Antioxidant, Antibacterial, Cytotoxic, and Apoptotic Activity of Stem Bark Extracts of Cephalotaxusgriffithii Hook. F. BMC Complementary and Alternative Medicine, 12, 30-36. http://dx.doi.org/10.1186/1472-6882-12-30

[25] Chen, C.-C., Wu, J.-H., Yang, N.-S., Chang, J.-Y., Kuo, C.-C., Wang, S.-Y. and Kuo, Y.-H. (2010) Cytotoxic C 35 Ter- 
penoid Cryptotrione from the Bark of Cryptomeria japonica. Organic Letters, 12, 2786-2789. http://dx.doi.org/10.1021/ol1009027

[26] Cowan, M.M. (1999) Plant Products as Antimicrobial Agents. Clinical Microbiology Reviews, 12, 564-582. http://cmr.asm.org/content/12/4/564.long

[27] Balasubramanian, S. and Eckert, R.L. (2007) Keratinocyte Proliferation, Differentiation, and Apoptosis-Differential Mechanisms of Regulation by Curcumin, EGCG and Apigenin. Toxicology and Applied Pharmacology, 224, 214-219. http://dx.doi.org/10.1016/j.taap.2007.03.020

[28] Bandar, H., Hijazi, A., Rammal, H., Hachem, A., Saad, Z. and Badran, B. (2013) Techniques for the Extraction of Bioactive Compounds from Lebanese Urtica dioica. American Journal of Phytomedicine and Clinical Therapeutics, 6 , 507-513. 
Scientific Research Publishing (SCIRP) is one of the largest Open Access journal publishers. It is currently publishing more than 200 open access, online, peer-reviewed journals covering a wide range of academic disciplines. SCIRP serves the worldwide academic communities and contributes to the progress and application of science with its publication.

Other selected journals from SCIRP are listed as below. Submit your manuscript to us via either submit@scirp.org or Online Submission Portal.
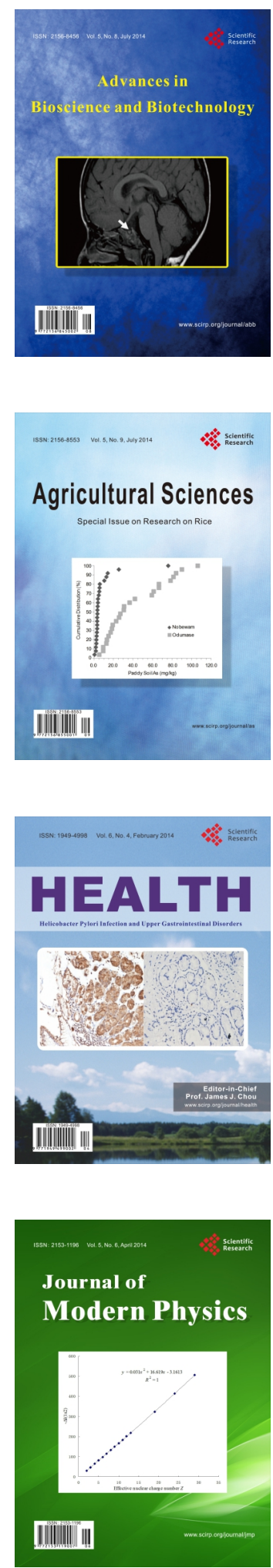
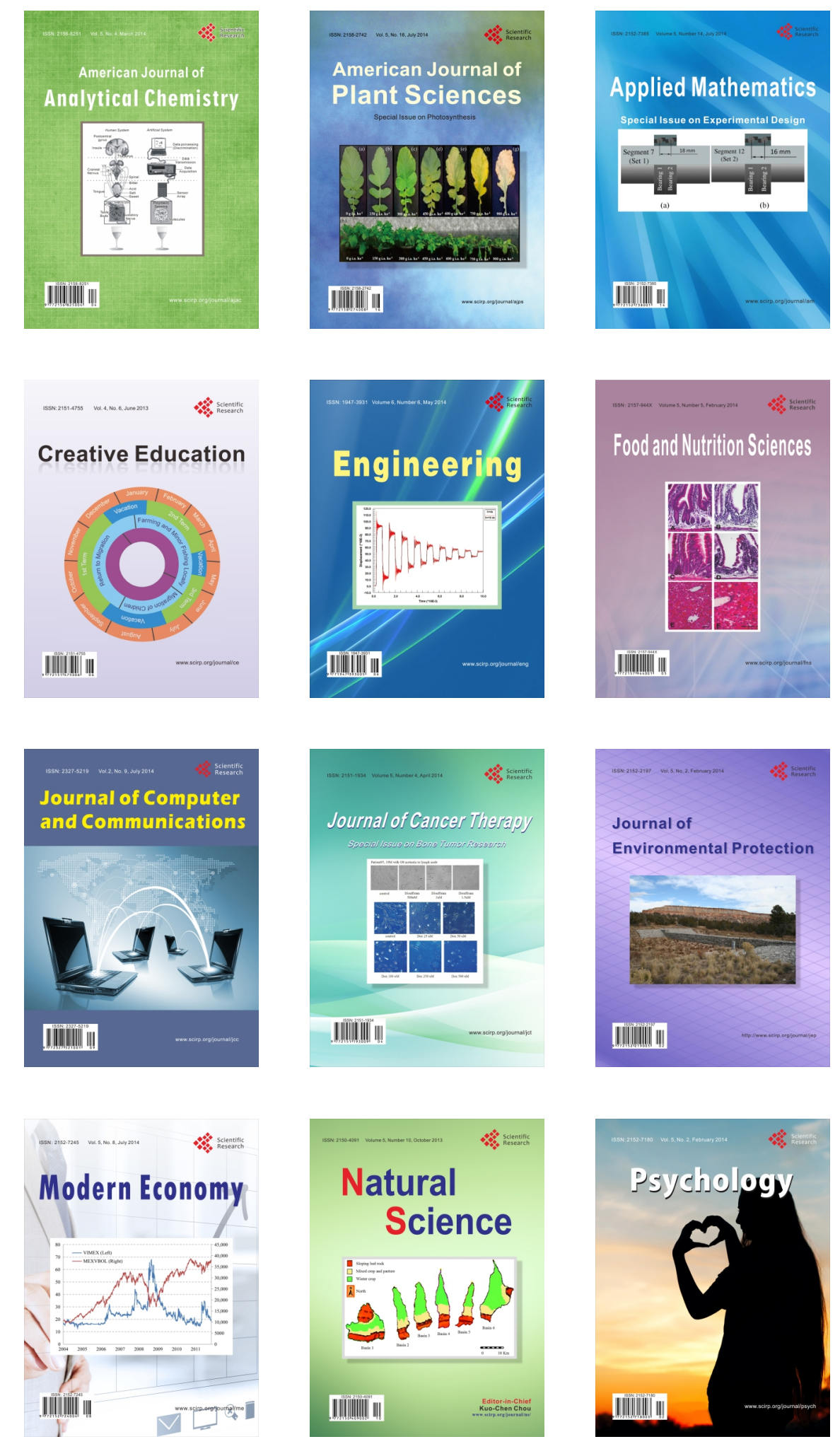